\title{
The Effect of Industrial Effluents on the Quality of Onukpawahe Stream, Tema-Ghana
}

\author{
Abdalla Abubakari ${ }^{1}$, Anyemedu Fredrick Oppong-Kyekyeku ${ }^{1}$, Donkor Emmanuel ${ }^{1}$ and Jackson Adiyiah \\ Nyantakyi $^{2,3}$ \\ 1. Environmental Protection Agency (EPA), Accra M326, Ghana \\ 2. Department of Civil Engineering, Kwame Nkrumah University of Science and Technology, PMB, Kumasi, Ghana \\ 3. Environmental Protection Agency (EPA), Sunyani 1505, Brong-Ahafo, Ghana
}

\begin{abstract}
Industrial effluents discharged into surface water body present a high percent of pollution in Ghanaian streams and rivers. The current study assessed the effects of industrial effluent on the quality of Onukpawahe stream which receives industrial effluents from the Tema Metropolis. Effluent samples were collected from six (6) selected industries and the water samples were collected from sixteen (16) different locations on the Onukpawahe stream. Various physico-chemical parameters such as BOD, TDS, Conductivity, COD, pH, TSS, Turbidity, Temperature, Colour, Sulphate, Phosphate, Ammonia and Nitrate were analysed during the current investigation. The average values of all the physico-chemical parameters (except pH and DO) were all above the EPA sector specific effluent guidelines. It was established in the study that the industries have polluted the stream and have grievously compromised the quality of the Onukpawahe stream. The surface water and industrial effluent must be monitored by the authorities in order to prevent further degradation of the river quality.
\end{abstract}

Key words: Onukpawahe stream, industrial effluent, water quality, physico-chemical parameters, EPA limits.

\section{Introduction}

The rapid growth in population, industrialization and the accompanying technology involves waste discharges and the rate at which these pollutants are discharged into the surface waters is far greater than the carrying capacities of these water bodies [1]. In Ghana, the main source of contamination of streams is the discharge of domestic wastewater from urban and town centers and the industrial effluents which bring about water borne diseases such as cholera. In view of this, assessing the quality of water is important for controlling contamination and the preservation of streams and rivers. According to Bartram and Balance [2], as the human population increases at a faster rate in the previous century, which leads to an increase in the demand for water the most essential commodity on

Corresponding author: Jackson Adiyiah Nyantakyi, principal programme officer, main reaearch field: water quality management. the earth, are increasingly pressurized and continually polluting the water bodies by agricultural, household waste and industrial effluents. Even though, a number of water quality assessments in terms of various physico-chemical, biological characteristics and heavy metals of surface water at various places in the Tema Metropolis have been carried out [3, 4], this research seeks to assess the effects of some industrial effluent on Onukpawahe stream in the Tema Metropolis in Ghana. The quality of any stream or river is influenced by human activities and natural sources [5]. The main sources of water for industrial, agricultural and households purposes within the catchment of these water bodies are usually these streams [6]. A related study by Koshy [7] reported that rivers or streams, though they are the most important water resources around the globe, are contaminated by rampant and uncontrolled discharges of domestic effluent, industrial effluent and anthropogenic activities [8]. The rate at which industrial wastewaters are released into streams 
and rivers is such that water bodies into which these wastewaters are released can no longer undergo the natural self-purification process as good quality water sources. Industrial effluent reveals different extent of environmental imbalance and degree of pollution load due to their chemical and microbial nature [9]. The consequences are high nutrient levels leading to dissolved oxygen depletion and the release of harmful substances which include heavy metals that could bioaccumulate in microorganisms in the water [10]. Microorganisms in streams or river bodies have the capacity to accumulate pollutants such as heavy metals, Polycyclic Aromatic Hydrocarbons (PAH) and Polychlorinated Biphenyl (PCB) in the environments which are persistent organic pollutants (POPs). When these contaminants are taken into the body they may not only cause procreative abilities of these microorganisms, but eventually cause impact on the health of human beings that depend on these microorganisms as their major source of protein food [11].

\section{Materials and Methods}

\subsection{Study Area}

The Onukpawahe stream is among the four major streams that drains into the Sakumonu lagoon which is a coastal lagoon situated $3 \mathrm{~km}$ west of Tema. The stream lies between longitude $5^{\circ} 39^{\prime} 24^{\prime \prime}$ to $5^{\circ} 39^{\prime} 35^{\prime \prime} \mathrm{N}$ and latitude $0^{\circ} 5^{\prime} 22^{\prime \prime}$ to $0^{\circ} 3$ ' $20^{\prime \prime} \mathrm{W}$. The Sakumono lagoon is an internationally recognized wetland. The catchment area is about $350 \mathrm{~km}^{2}$. The major streams that drain the basin are Onukpawahe, Mamahoma, Dzorwulu and Gbagbla-Akornu streams. The Onukpawahe stream is a major source for agriculture (i.e. fruit and vegetables) activities located in the upstream and downstream areas and is about $12.8 \mathrm{~km}$ long. The study was carried out in Onukpawahe stream that transverses the Tema Motorway industrial and in effluent channel from six (6) industries. Fig. 1 shows the study area and sampling locations.

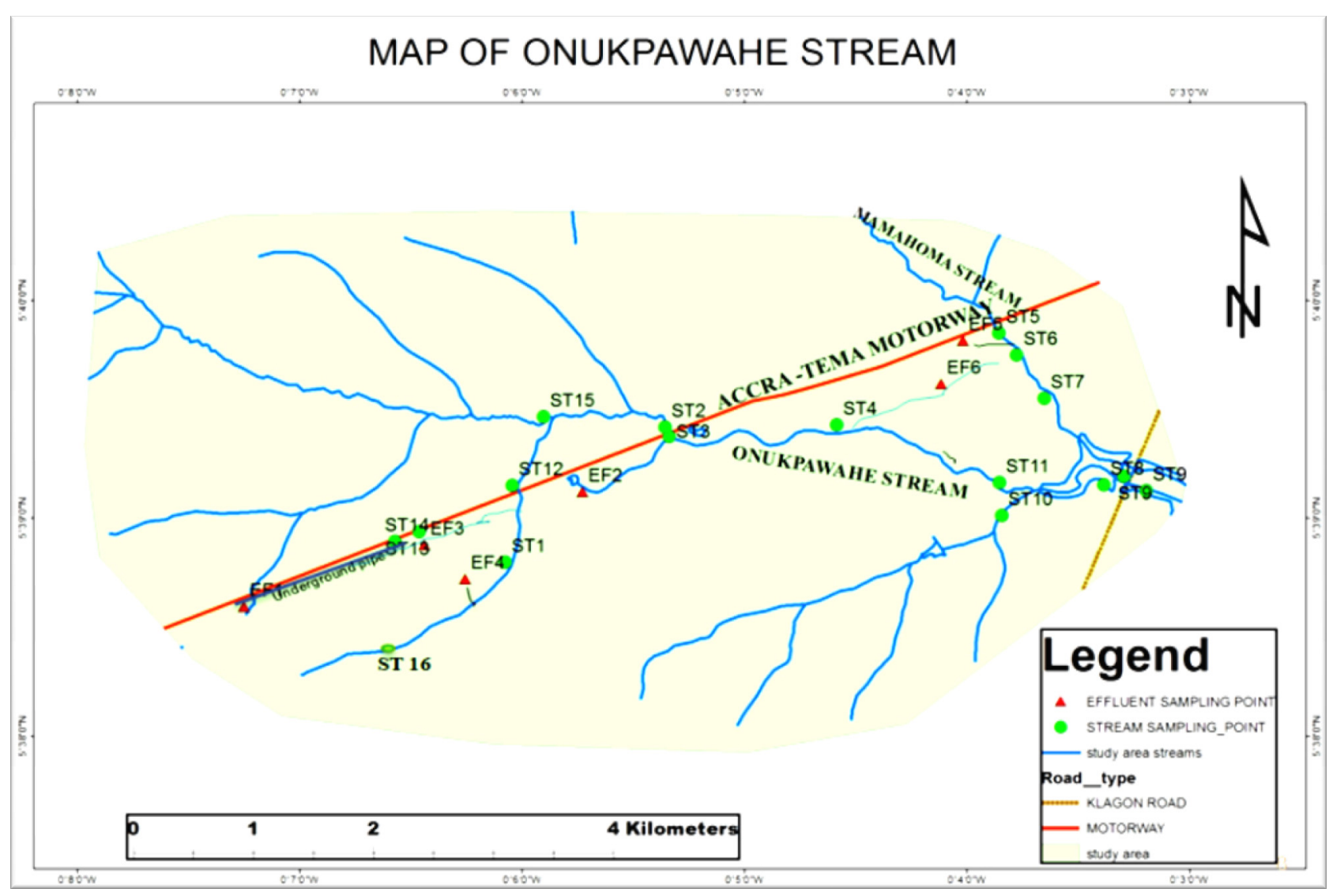

Fig. 1 Map showing study area and sampling locations. 


\subsection{Samples Collection and Analysis}

The effluent samples were collected from six (6) selected industries and stream samples at sixteen (16) selected points along the receiving streams that drain Tema Motorway industrial area (Fig. 1). The industries mainly discharge their effluents into the Onukpawahe stream. The sampling took place for five months (October 2015-February 2016). The period between October-November, 2015 was considered the wet season, while the period between December, 2015-February, 2016 was considered the dry season. The GPS Coordinates were recorded for each sampling site. The sampling points were designed in relation to industries as depicted by Fig. 1. All samples for laboratory analysis were placed into thoroughly cleaned (with dilute $\mathrm{HNO}_{3}$ and rinsed with distilled water before use) 1 litre plastic bottles and glass bottles. Each of these bottles was rinsed with appropriate amount of water or effluent sample before collecting the sample. The samples were placed in cooler boxes which were protected from sunlight before taken to laboratory for analysis. The analysis of the physical parameters of the effluent and water sample was carried out in situ using multi-parameter water quality meter (Horriba U-52G). The following parameters were measured in situ, $\mathrm{pH}$, Temperature, Turbidity, DO, Conductivity and TDS. The water and effluent quality parameters such as Nitrate-nitrogen, Ammonia-nitrogen, sulphate and phosphate were total determined with WagtechPotalab Photometer Model 7100 using the correct reagent tablets at the Environmental Quality Laboratory at the Environmental Quality Department of Environmental Protection Agency (EPA), Accra. Biochemical Oxygen Demand $\left(\mathrm{BOD}_{5}\right)$ was determined by the Velp Scientific System (Incubator). The Velp system uses $\mathrm{BOD}_{5}$ sensor which records $\mathrm{BOD}_{5}$ every 24 hours for 5 days incubation. Extensive field work on the identification of industries discharging into Onukpawahe stream as source of pollution was carried out within the catchment of the stream. One way ANOVA with $5 \%$ significant levels was used to determine the significant differences between the locations and the state of the stream respectively.

\section{Results and Discussion}

\subsection{General Overview of the Industrial Effluent Quality}

The physical and chemical parameters selected in this study were based on the Environmental Protection Agency (EPA) requirements, in terms of the EPA sector specific effluent guidelines. A comparison of the measured parameters with the EPA sector specific effluent guidelines showed that $\mathrm{BOD}_{5}, \mathrm{COD}$ and nutrients exceeded the EPA effluent quality guidelines (Figs. 2-27). The authorities in EPA and Water Resources Commission are being entreated to intensify their monitoring activities in the said industries in the Tema Metropolis to avert further degradation of the Onukpawahe stream.

\subsection{Physico-chemical Parameters in Effluent and Stream}

\section{$3.2 .1 \mathrm{pH}$}

The $\mathrm{pH}$ of the Onukpawahe stream ranges from 5.36 to 10.05 in the wet season and 6.63 to 8.36 in the dry season. The highest $\mathrm{pH}$ values of 10.05 was obtained at station ST1 in the Wet season, whereas the lower mean values of 5.36 was obtained at station ST3 in the wet period (Fig. 2). However, the $\mathrm{pH}$ observed in the effluents of the industries in the wet period were $5.52 \pm 0.59$ from industry EF1, $4.725 \pm 1.96$ from industry EF2, $8.8 \pm 0.22$ in the effluent of EF3, $5.83 \pm$ 0.21 in the effluent of industry EF4, $6.21 \pm 0.18$ in the effluent of industry EF5 and $6.61 \pm 0.22$ in the effluent of industry EF6 (Fig. 3), whereas in the dry period, the $\mathrm{pH}$ values recorded were $6.36 \pm 0.25$ from industry EF1, $5.43 \pm 0.22$ from industry EF2, $9.2 \pm$ 0.66 in the effluent of EF3, $6.24 \pm 0.78$ in the effluent of EF4, $5.71 \pm 1.55$ in the effluent of EF5 and $7.45 \pm$ 


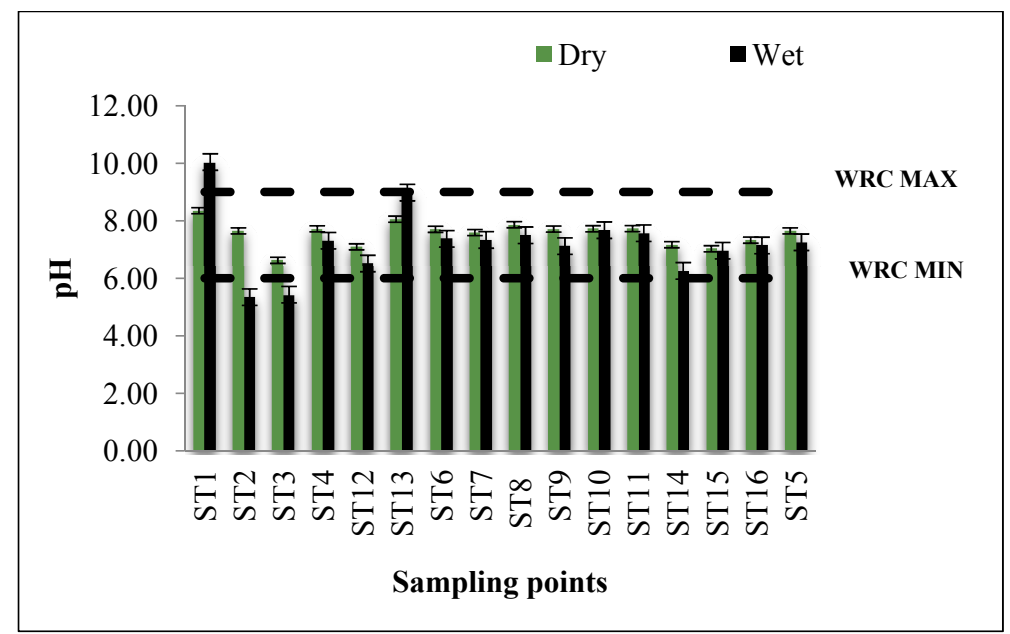

Fig. 2 pH of the stream.

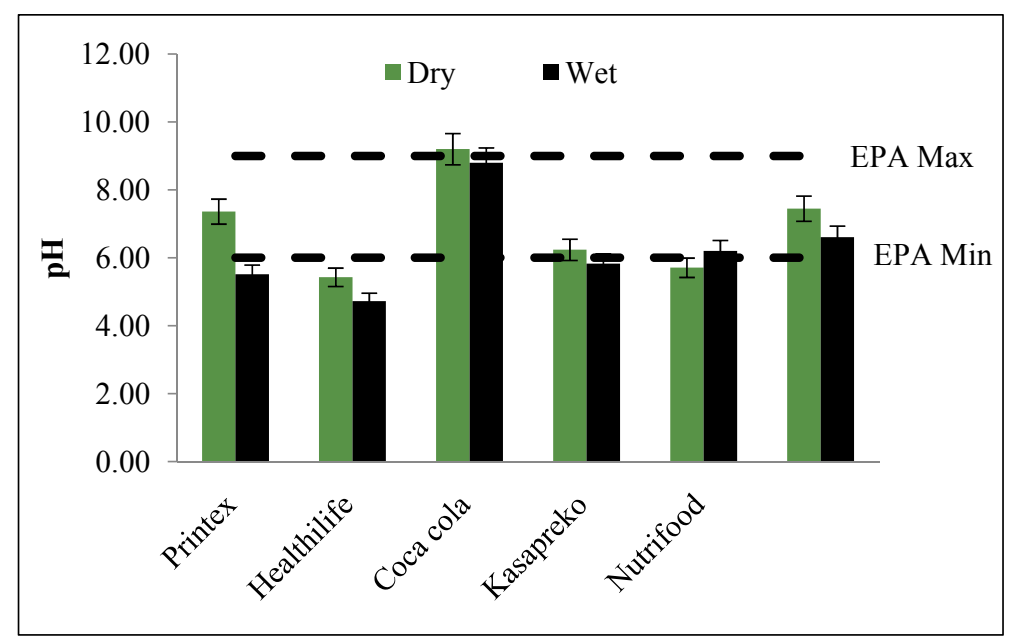

Fig. 3 pH of the industries.

0.42 in the effluent from industry EF6 (Fig. 3). The low $\mathrm{pH}$ values were recorded at mid- stream station ST2 and ST3 where most of the beverage industries including brewery industries are discharging their effluent into the stream and this could attributed to raw material such as grains and yeast and have peculiar stench of rancid malt and partially acidulous [12]. The high $\mathrm{pH}$ at site ST1 (10.05) could attributed to photosynthetic activities of algae that consume carbon (IV) oxide dissolved in the stream (Fig. 2). The $\mathrm{pH}$ values recorded in the stream were all within the WRC raw water quality guideline "no effect" range of 6.0-9.0 [13] except the $\mathrm{pH}$ values observed at sites ST1, ST2 and ST13 (Fig. 2). Moreover, the differences between the $\mathrm{pH}$ concentration were observed to be statistically insignificant (ANOVA, $\mathrm{p}=0.29, \mathrm{P}>$ 0.05). The high $\mathrm{pH}$ observed at industry EF3 could be attributed to the pretreatment process of the influence. Washing of bottles and cleaning where a lot of caustic materials were used as cleaning agents (detergents and $\mathrm{NaOH}$ ) and additives for food and beverages (e.g. sodium benzoate- $\mathrm{C}_{6} \mathrm{H}_{5} \mathrm{COONa}$ and common salt- $\mathrm{NaCl}$ ) are used. Similar observations were made by Refs. [14, 15] on the Kumasi Coca Cola Plant which indicated that the influence wastewater was alkaline (11.3), and after treatment, $\mathrm{pH}$ (8.9) alkaline. The $\mathrm{pH}$ has great impact on the stream quality by affecting the metals solubility, the alkalinity, and hardness of the water. Since most metabolic activities of aquatic organisms depend on $\mathrm{pH}$, the aquatic life is affected $[16,17]$. 


\subsubsection{Dissolved Oxygen (DO)}

Dissolved Oxygen is important in the determination of the quality of stream water and also assists in the understanding of the natural self-purification ability of water as well as the impacts of urbanization and industrialization on water [18, 19]. The Dissolved Oxygen (DO) levels in the stream water samples analyzed were between $5.60 \mathrm{mg} / \mathrm{L}$ to $8.50 \mathrm{mg} / \mathrm{L}$ in the wet period and from $4.70 \mathrm{mg} / \mathrm{L}$ to $7.90 \mathrm{mg} / \mathrm{L}$ in the dry period. The lowest DO was recorded at site ST6, whereas the maximum value was observed at site ST3 in the wet period (Fig. 4). The differences between sampling site was statistically insignificant (ANOVA, $\mathrm{P}=0.522, \mathrm{P}>0.05)$. However, the observed DO levels in the stream water samples were within the WRC raw water guideline "no effect" range of 0-5
mg/L [16] except site ST2 and ST6 (Fig. 4). The results obtained in the effluent samples were within the EPA effluent quality guideline value of more than $5 \mathrm{mg} / \mathrm{L}$. The Dissolved Oxygen (DO) concentration in the industrial effluent of study ranged from $3.89 \mathrm{mg} / \mathrm{L}$ (EF6)-7.67 mg/L (EF5) and $4.68 \mathrm{mg} / \mathrm{L}$ (EF6)-9.27 $\mathrm{mg} / \mathrm{L}(\mathrm{EF} 5)$ in the dry and wet periods respectively (Fig. 5). The low DO observed in the effluent from the industry EF6 (Abattoir) is an indication of discharge of high degradable organic load, which eventually consume the oxygen in the receiving water body. This implies that no oxygen will present for aquatic microorganism which are stressed, suffocate, and die. The consequence is that there will be no aquatic life at this part of the stream. Similar findings have been reported by Refs. [20, 21].

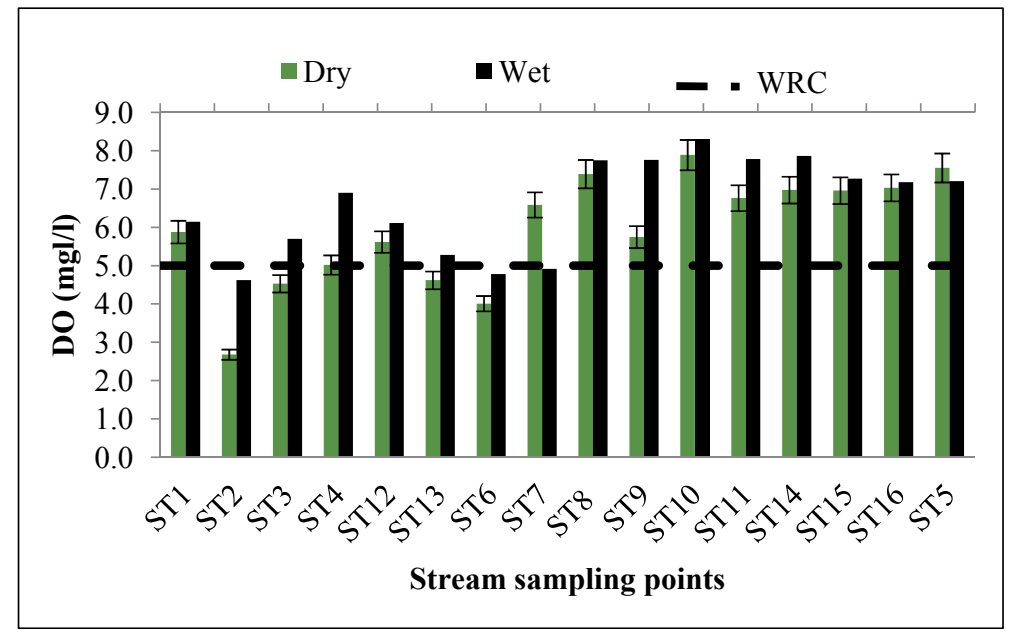

Fig. 4 DO of the stream.

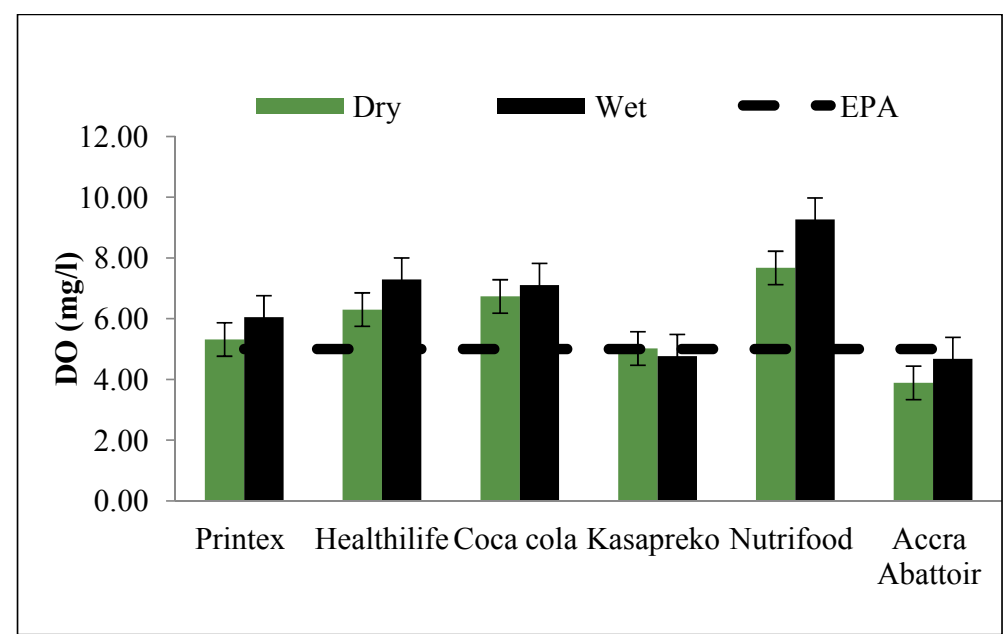

Fig. 5 DO of the industries. 


\subsubsection{Total Dissolved Solids (TDS)}

The TDS recorded in the stream ranged between 173 to $2,503 \mathrm{ppm}$ in the wet period, whereas in the dry period it ranges from 71 to $1,785 \mathrm{mg} / \mathrm{L}$. However, the TDS concentration recorded in the industrial effluent samples ranged between a low value of $325 \mathrm{ppm}(\mathrm{EF} 2)$ to 3,288 ppm (EF6) and $255 \mathrm{ppm}$ (EF1) to 1,275 ppm (EF6) in the dry and wet periods respectively (Figs. 6 $\& 7)$. The TDS concentration recorded in the stream were above the Water Resource Commission (WRC) raw water quality guideline "no effect" range of 0-450 $\mathrm{mg} / \mathrm{L}$ [16] except the upstream sites ST14, ST15 and ST16. During the dry period the level of TDS were much lower than the rainy season (Fig. 6), while the TDS levels observed in the effluent samples were above the EPA effluent quality guideline value of 1,000 ppm. Moreover, (ANOVA, $\mathrm{P}=0.005, \mathrm{P}<0.05$ ) indicates that the difference in the concentration of TDS between the sites is statistically significant. The high concentration of TDS observed in the stream during the wet period could be attributed to runoff from the farmlands that brought into the stream chemical materials like phosphate, chloride and nitrates from fertilizer [22]. The effluent samples from industry EF6 (Abattoir) and EF3 (beverage) were relatively characterized with high level of TDS. The high TDS levels in effluent could be attributed to partly digested diet in the gut of process animals which usually contain nitrogenous substance [21] and inorganic solids such as chloride, nitrate, and phosphate anions.

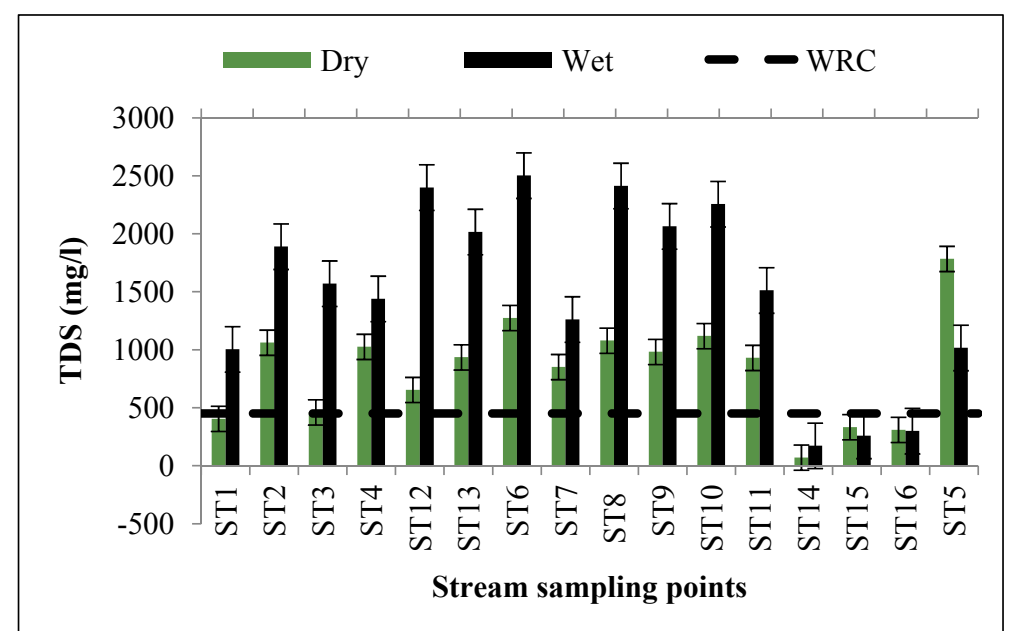

Fig. 6 TDS of the stream.

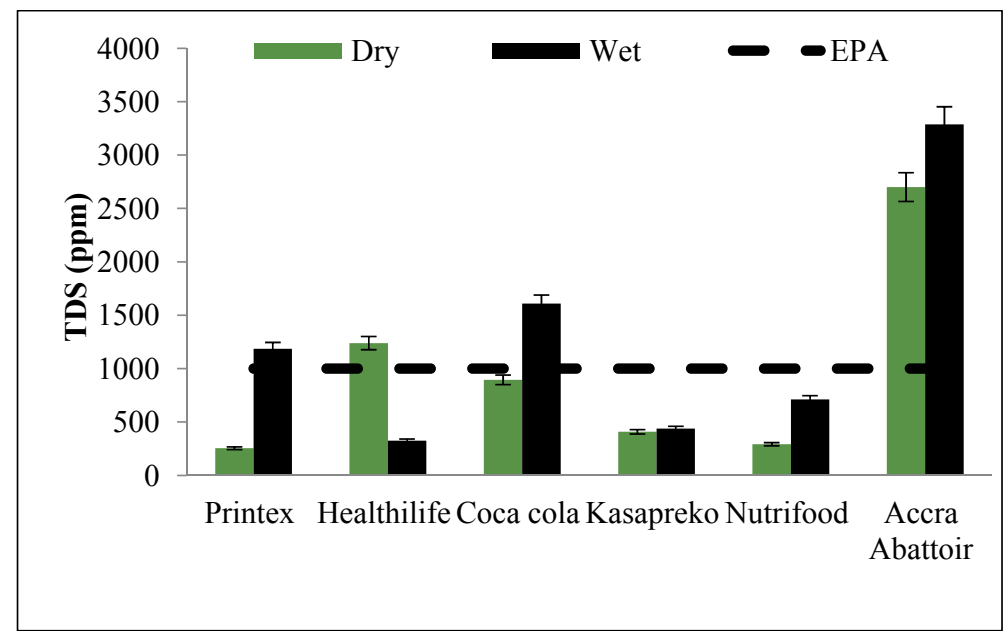

Fig. 7 TDS of the industries. 


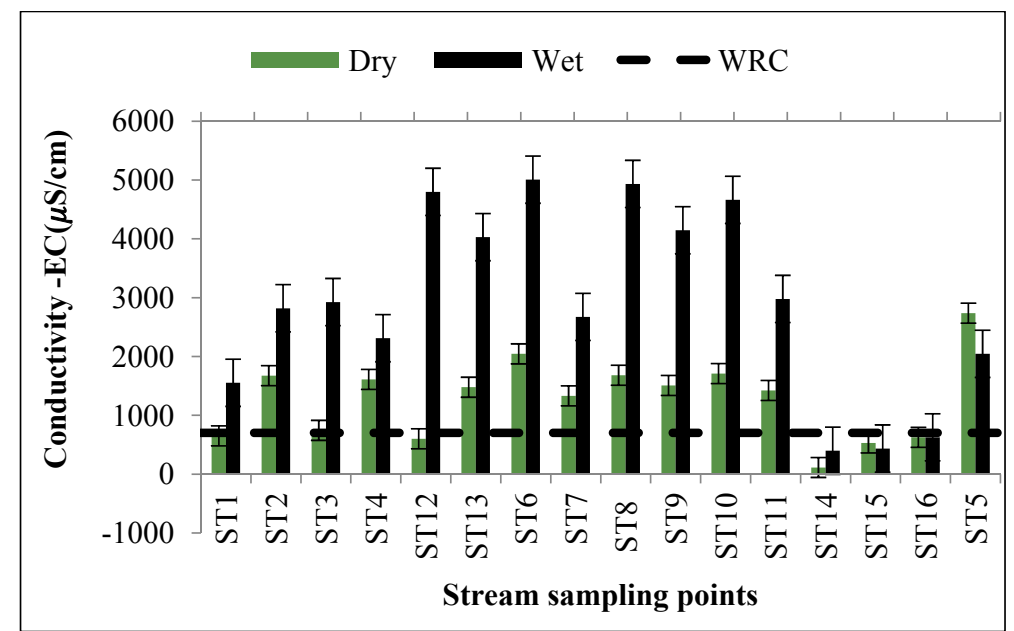

Fig. 8 EC of the stream.

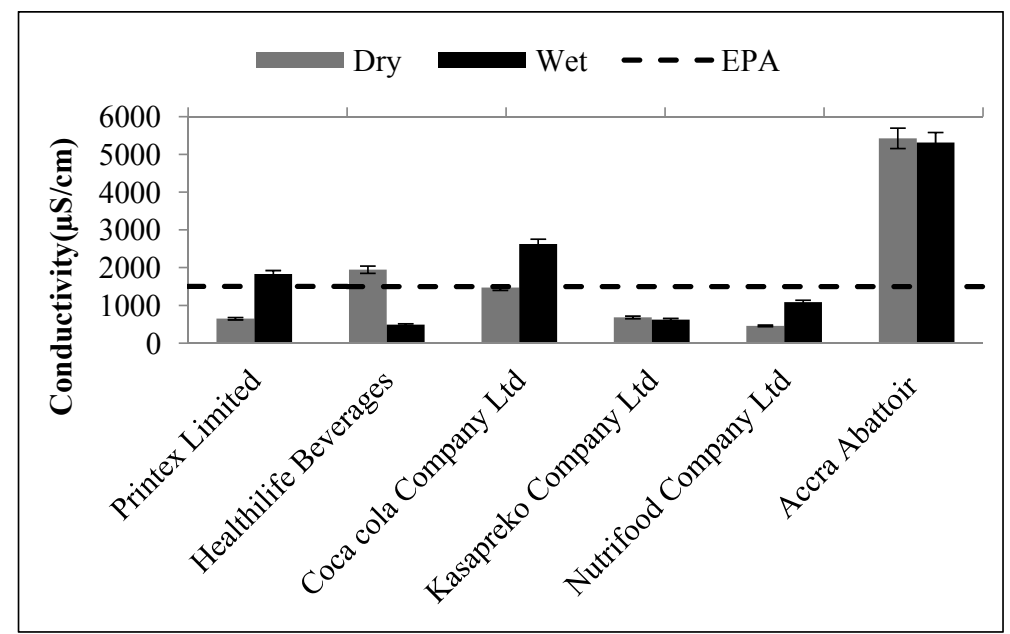

Fig. 9 EC of the industries.

TDS are influenced by the existence of inorganic substances (phosphate, chloride and nitrate ions) and the high level of these solids in water leads to nutrient enrichment which affects aquatic life. Also the high level of TDS is an indication of salinity and eutrophication [19].

\subsubsection{Electrical Conductivity (EC)}

The conductivity ranges between $398 \mu \mathrm{S} / \mathrm{cm}$ and $5,006 \mu \mathrm{S} / \mathrm{cm}$ in the wet period and the minimum was observed at site ST14 (Fig. 8), while the highest was at site ST6 (Fig. 8). Similarly, conductivity varied in the dry season from $113 \mu \mathrm{S} / \mathrm{cm}$ to $2,737 \mu \mathrm{S} / \mathrm{cm}$ (Fig. 6) and the lowest value was obtained at site ST14, while the highest was at site ST5 (Fig. 8). The conductivity levels observed in the stream water samples were above the Water Resource Commission (WRC) raw water quality guideline values "no effect" range of 0-700 $\mu \mathrm{S} / \mathrm{cm}[16]$ except upstream sites ST14, ST15 and ST16. Moreover, ANOVA P $=0.001$, (ANOVA, $P<0.05)$ indicates that the differences in conductivity levels between the sites was statistically significant. Similarly, the conductivity values recorded in the industrial effluent range from a low value of 459 $\mu \mathrm{S} / \mathrm{cm}$ in the effluent of industry EF5 (biscuit plant) to a high of $5,425 \mu \mathrm{S} / \mathrm{cm}$ in the effluent of industry EF6 (Abattoir) (Fig. 9). Generally the values were above the EPA effluent quality guideline values of 1,500 $\mu \mathrm{S} / \mathrm{cm}$ before discharge into natural water body [22] The high conductivity level in these industrial effluents is ascribed to the presence of ions which include chlorides, phosphates and nitrates [23]. The high conductivity levels in the effluent samples is due 
to nitrogen substances in a form of partly digested diet in the gut of process animals and spent yeast, dyes and organic waste. These high level discharges into the Onukpawahe stream are adversely affecting the humans and aquatic habitat.

\subsubsection{Total Suspended Solids (TSS)}

The concentration of TSS was found ranging from $117 \mathrm{mg} / \mathrm{L}$ to $788 \mathrm{mg} / \mathrm{L}$ in the wet period and $48 \mathrm{mg} / \mathrm{L}$ to $224 \mathrm{mg} / \mathrm{L}$ in the dry period. The high TSS levels during the wet period is due to the mixing of higher level of catchment washing through large number of discharges and dry season showed comparatively low level of TSS (Fig. 10). The TSS values observed were far higher than the WRC raw water quality guideline "no effect" range of $0-5 \mathrm{mg} / \mathrm{L}$ [32]. However, the
(ANOVA, $\mathrm{P}=0.005, \mathrm{P}<0.05$ ) indicates statistically significant differences in the concentration between sites. Moreover, the value of TSS in the effluent were from low of $92 \mathrm{mg} / \mathrm{L}$ in the wastewater from industry EF3 (beverage plant) to a high value of $509 \mathrm{mg} / \mathrm{L}$ in the effluent of industry EF6 (Abattoir) (Fig. 11). The recorded values of TSS were all above the EPA, Ghana guideline value of $50 \mathrm{mg} / \mathrm{L}$ [23] in both the period (wet \& Dry). The high TSS in the industrial effluent could be due to the fact that these effluent are usually constituted with microbes, degradable substance and plankton from their production processes especially EF6 (Abattoir). Similar research by Adeogun [24] reveals that TSS in River Galma, Zaria Nigeria contains particles such as clay, silt organic and inorganic

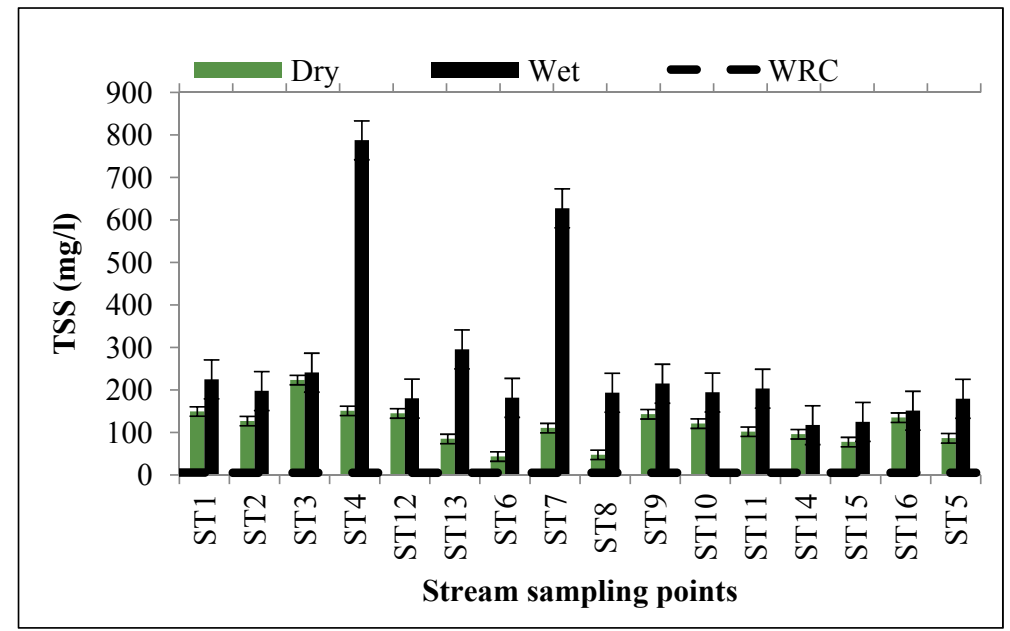

Fig. 10 TSS of the stream.

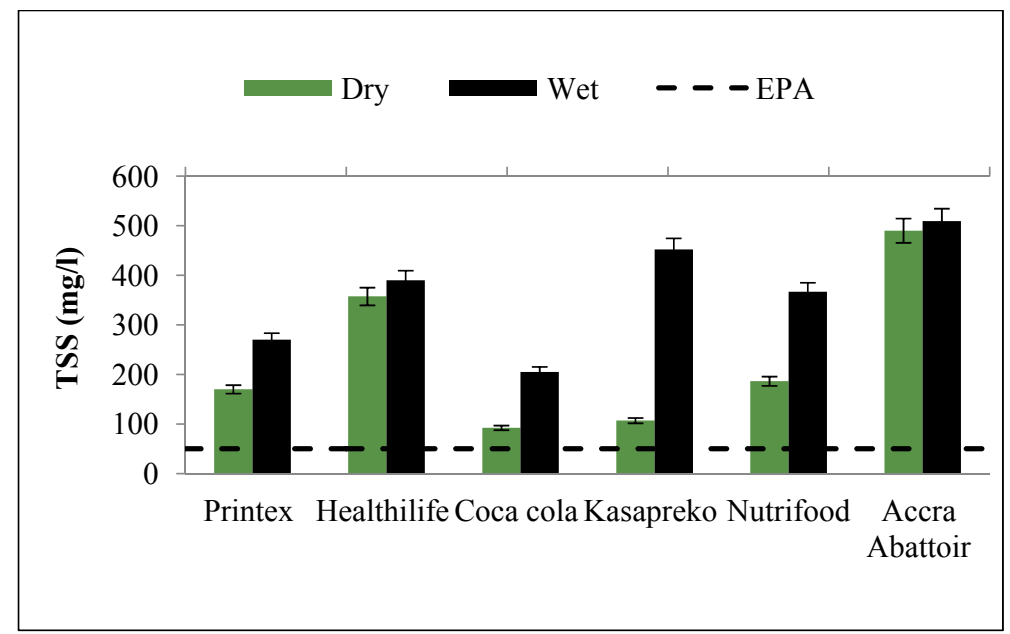

Fig. 11 TSS of the industries. 


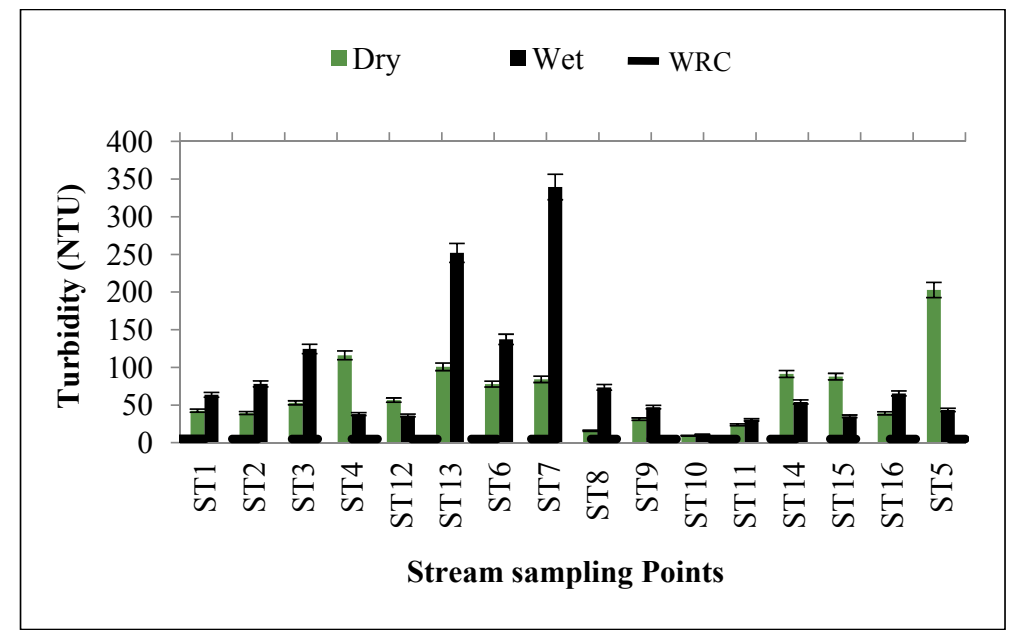

Fig. 12 Turbidity of the stream.

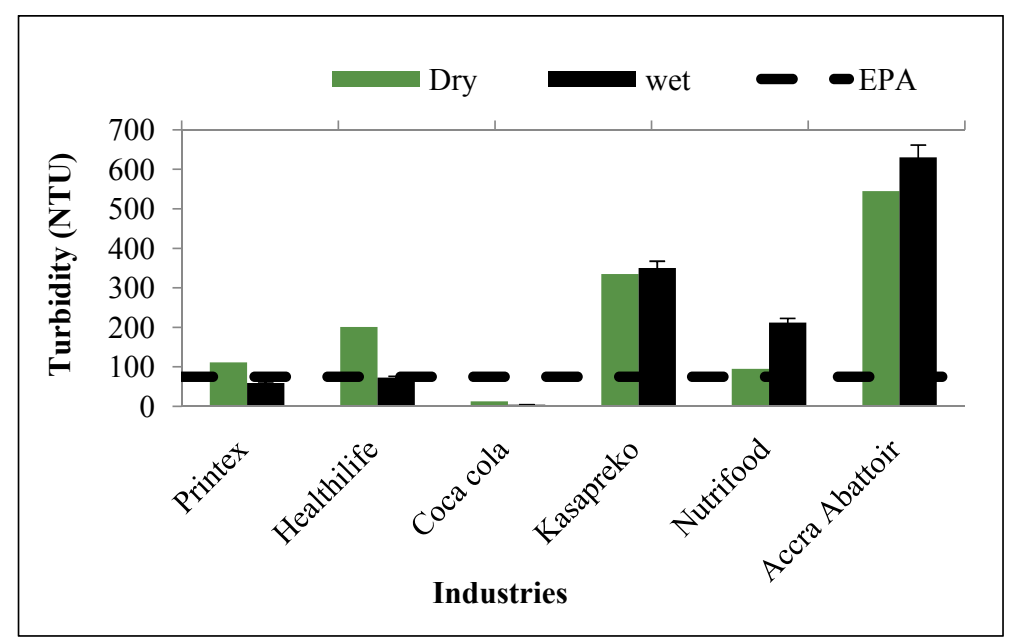

Fig.13 Turbidity of the industries.

substances. The impact of TSS is affecting fish feeding and growth, light penetration in water for production of food (photosynthesis) and supports microbial pollution which are harmful to humans because suspended particle serve as attachment side for bacteria.

\subsubsection{Turbidity}

The turbidity levels observed in the wet season were between $11 \mathrm{NTU}$ and 340 NTU, whereas it ranges from 9 NTU to 203 NTU in the dry season (Fig. 12). The highest turbidity was recorded at downstream site ST7 and the lowest was recorded at site ST10 which is located within residential areas (Fig. 12). The turbidity values observed during the study were far higher than the WRC raw water quality guideline values the "no effect" range of 0-5 NTU [16]. This implies that in the wet season, the stream carried an associated risk of disease transmission due to infectious disease agents and chemicals absorbed. However, the ANOVA $(\mathrm{P}<0.05)$ indicates that there was a significant difference between the turbidity levels among sites. The high turbidity recorded at site ST7 could be attributed to the release of effluent with high suspended substance from the industries especially the Abattoir into Onukpawahe stream [21]. The turbidity level in the effluent samples ranged from a low value of 13 NTU in the effluent of the industry EF3 (beverage) to high concentration value of 630 NTU in the effluent of industry EF6 (Abattoir) (Fig. 13). The high levels of turbidity in the stream could be attributed to the discharge of textile effluent (organic substances), run-off from vegetables farms or 


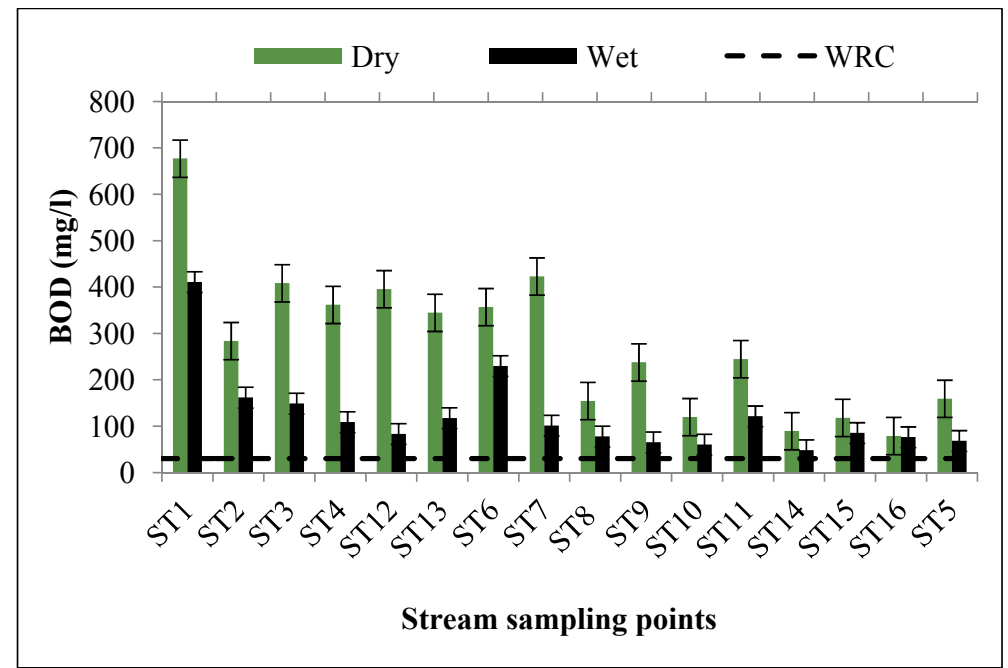

Fig. 14 BOD of the stream.

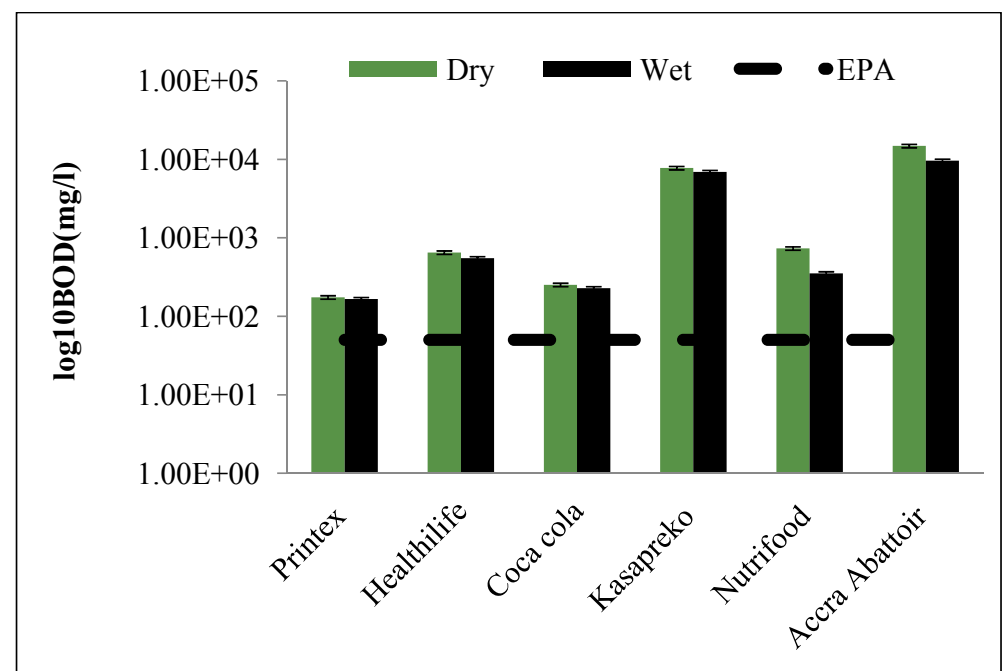

Fig. 15 BOD of the industries.

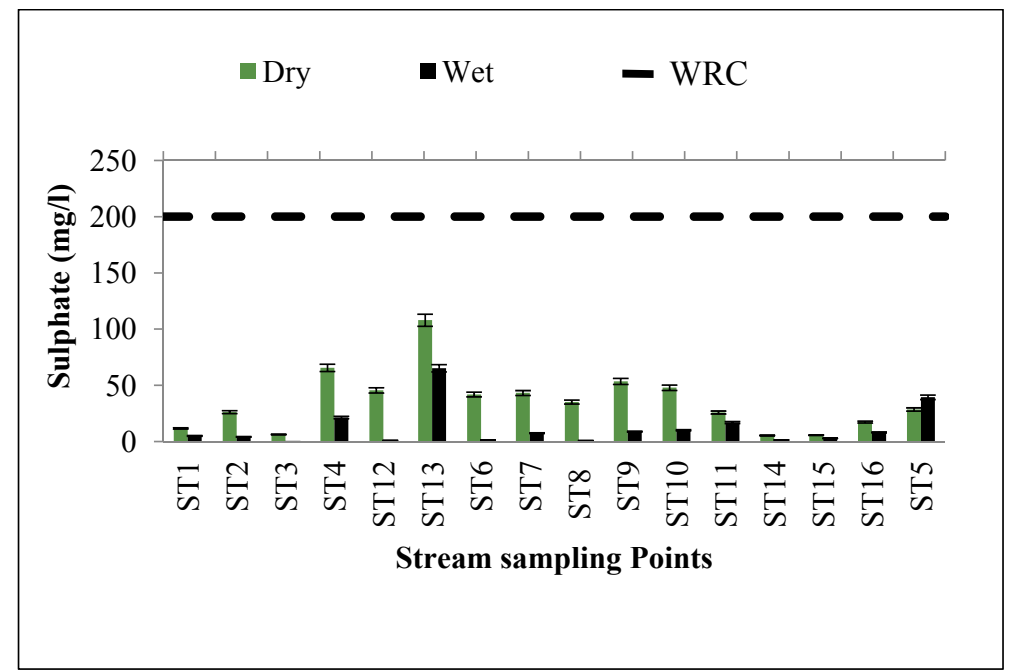

Fig.16 Sulphate of the stream. 


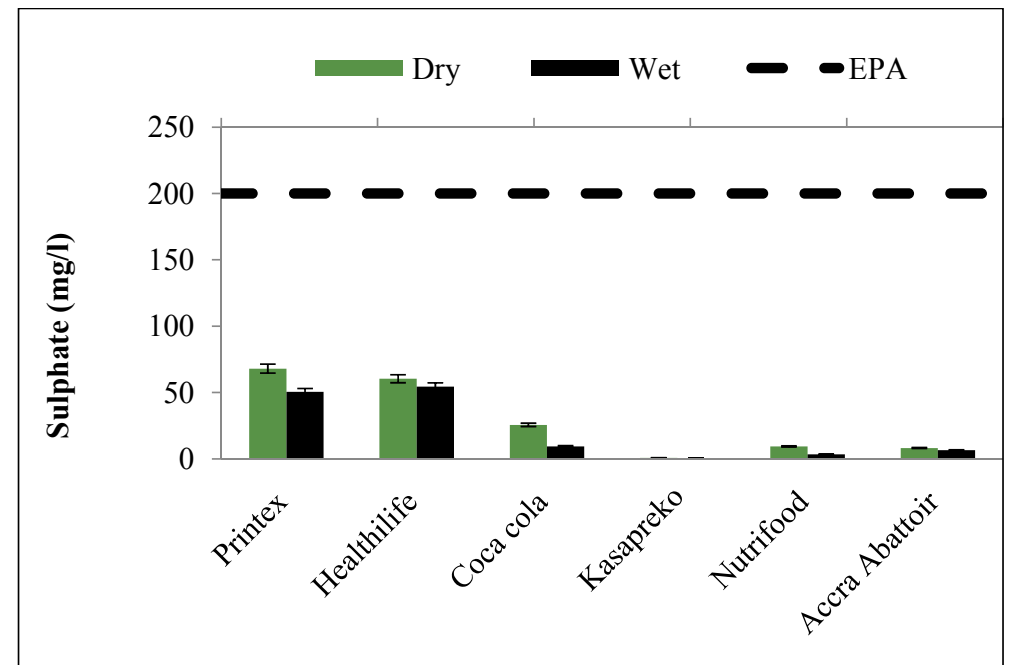

Fig. 17 Sulphate of the industries.

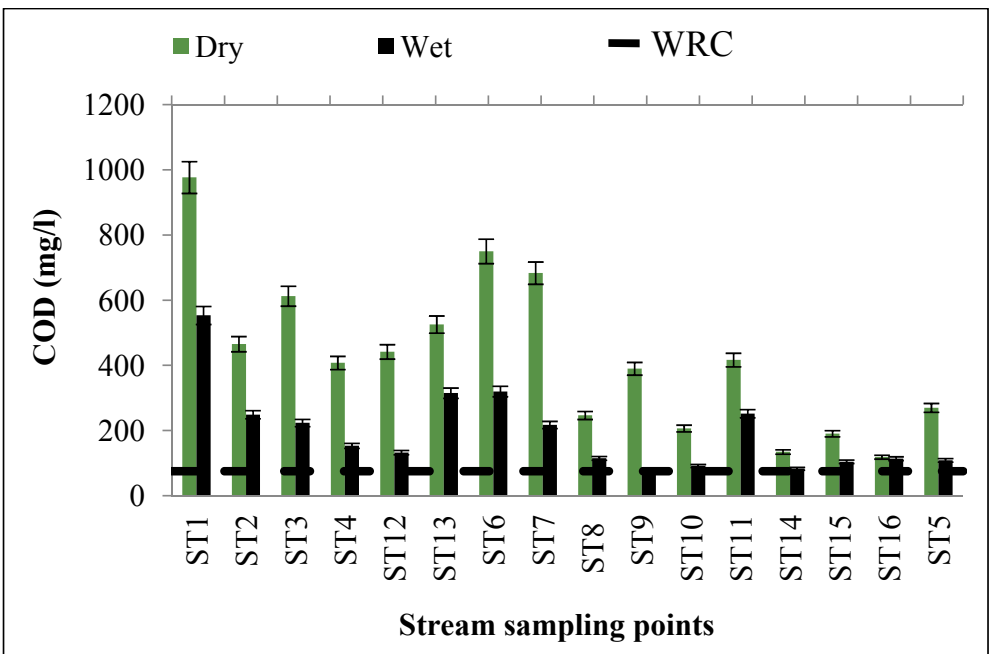

Fig. 18 COD of the stream.

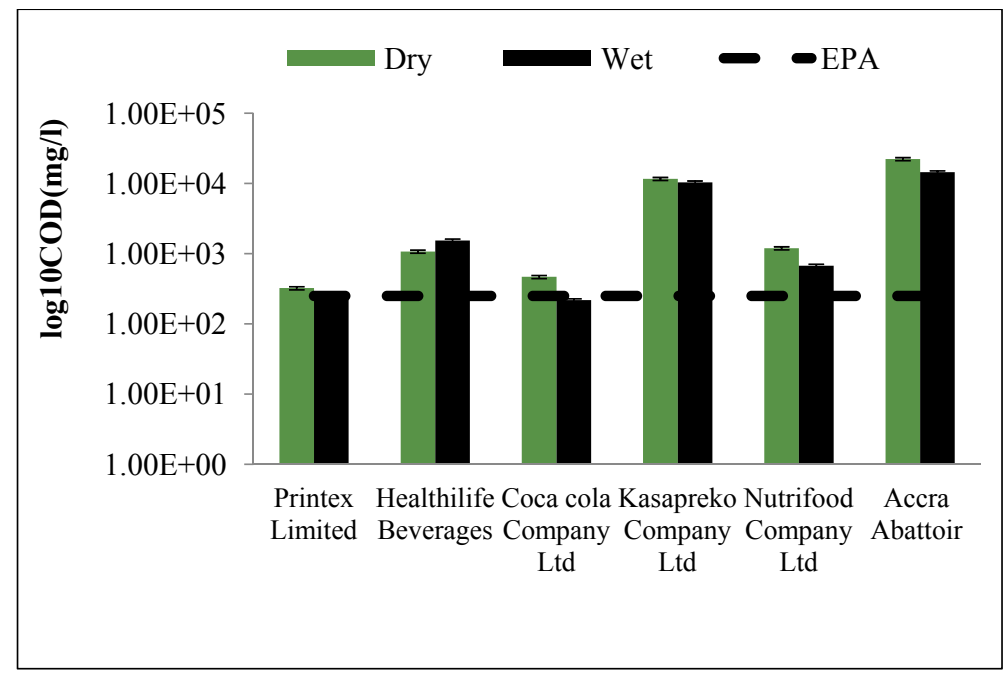

Fig. 19 COD of the industries. 
roads and heavy precipitation into the stream could also account for the increase in turbidity. Increased turbidity reduces light penetration needed for photosynthesis by some aquatic life [26, 27]. When these organic wastes are continuous discharge into the aquatic ecosystem will terminate the aquatic life and emanate foul odour into the environment.

\subsubsection{Colour}

According to Sirohi, et al. [28], colours in natural waters could attribute to the decay of organic substances and discharge of certain waste. The recorded colour in the stream water samples ranges from 66 TCU at site ST16 (upstream station) to 783 TCU at site ST4 in the dry period, whereas in the wet period it ranges from $32.5 \mathrm{TCU}$ at site ST8 to 297 TCU at site ST4 (Fig. 26). The observed colour in the stream was far higher than the WRC raw water quality guideline "no effect" range of 0-15 TCU [16] (Fig. 26). The difference in concentrations between sites were not statistically significant (ANOVA, P $=0.056, \mathrm{P}>$ 0.05 ). The colour observed in the industrial effluent ranges from a low $149 \mathrm{TCU}$ in the effluent of industry EF3 (beverage plant) to a high of 1,310 TCU in the effluent of industry EF6 (slaughter house) in the dry period, whereas from a low of 95 TCU in the effluent of EF5 (fruit juice) to a high of $465 \mathrm{TCU}$ in the effluent of industry EF1 (textile) (Fig. 27). The concentrations recorded in the effluent were above the EPA effluent quality guideline value of 200 TCU [22], (Fig. 27) The low recorded colour values upstream and the high values downstream throughout the entire period is an indication of the relative state of the downstream water impacted by industrial effluent [25]. The change in colour downstream may be as a result of organic dyestuff and organic substances in the industrial effluent discharge by Textile and the Beverage industries. The high colour could interfere with light penetration and affect photosynthesis which could affect aquatic life.

3.2.8 Ammonia-nitrogen

The concentration of ammonia-nitrogen of stream samples was between $0.01 \mathrm{mg} / \mathrm{L}$ and $0.90 \mathrm{mg} / \mathrm{L}$ and between $0.01 \mathrm{mg} / \mathrm{L}$ and $16 \mathrm{mg} / \mathrm{L}$ in the dry and wet periods respectively (Fig. 20). However, the levels in the industrial effluent samples were found to be betweena low of $(0.58 \mathrm{mg} / \mathrm{L} \& 0.28 \mathrm{mg} / \mathrm{L})$ in the effluent of industry EF3 (beverage plant) for both period and high value $(5.78 \mathrm{mg} / \mathrm{L} \& 5.07 \mathrm{mg} / \mathrm{L})$ in the effluent of EF1 (Textile) for both dry and wet periods (Fig. 21). Moreover, the ammonia-nitrogen recorded throughout the study period were within the WRC raw water quality guideline values the "no effect" range of $0-1 \mathrm{mg} / \mathrm{L}$ [15] except for site ST1 which value was observed to be $16 \mathrm{mg} / \mathrm{L}$ in the wet period, while the concentration of ammonia observed in the effluent samples were within EPA effluent quality guideline value except at industry EF2. The ANOVA $(\mathrm{P}=0.350, \mathrm{P}>0.05)$ indicates that the difference between the sites interns of concentrations were statistically insignificant. From available literature [25], high concentration of ammonia in the stream could be due to ammonium bicarbonate which is used as part of the biscuit production process which effluent is discharged into the Onukpawahe stream. The discharge of animal waste from Abattoir and organic load such as dyes for textile production are also possible source of ammonia. When effluent with some levels ammonia levels are discharge continually, it may cause algal outbreaks (eutrophication) in Onukpawahe Stream. According to Ipeaiyeda and Onianwa [30], these algal eventually dies and decompose and consequently deplete the dissolved oxygen in the stream and this could result in the death of aquatic flora and fauna releasing high odour into environment.

\subsubsection{Phosphate}

The concentrations of phosphate in the stream samples spanned over $17.93 \mathrm{mg} / \mathrm{L}$ to $99.70 \mathrm{mg} / \mathrm{L}$ and between $2.5 \mathrm{mg} / \mathrm{L}$ and $83 \mathrm{mg} / \mathrm{L}$ in the dry and wet seasons respectively (Fig. 22). However, the levels of phosphate in the industrial effluent samples were between $0.285 \mathrm{mg} / \mathrm{L}$ and $0.553 \mathrm{mg} / \mathrm{L}$ in the effluent of industry EF3 (Beverage) in both periods and high 


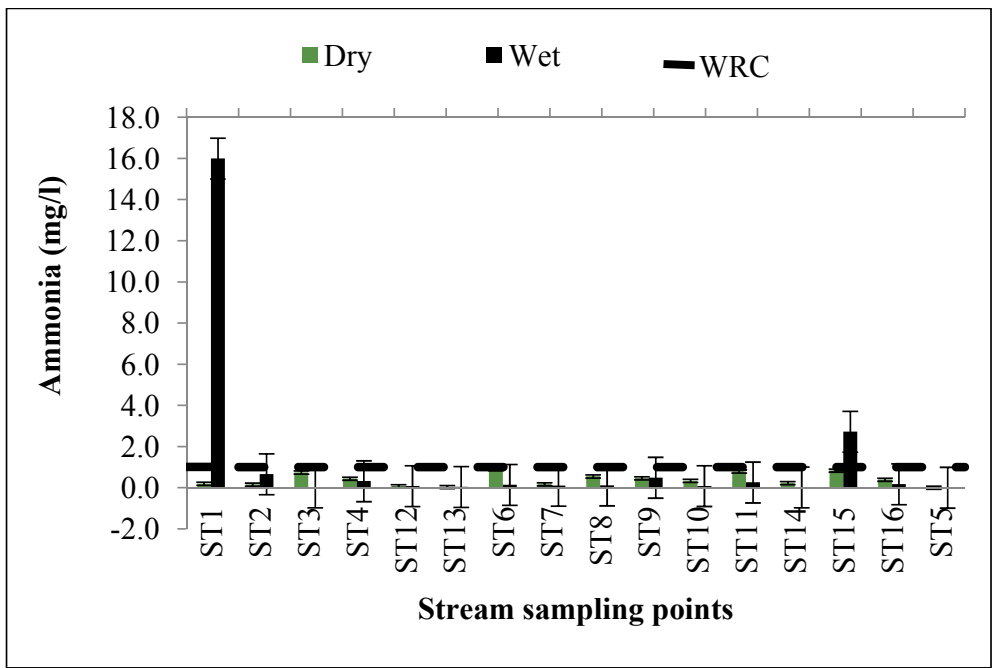

Fig. 20 Ammonia of the stream.

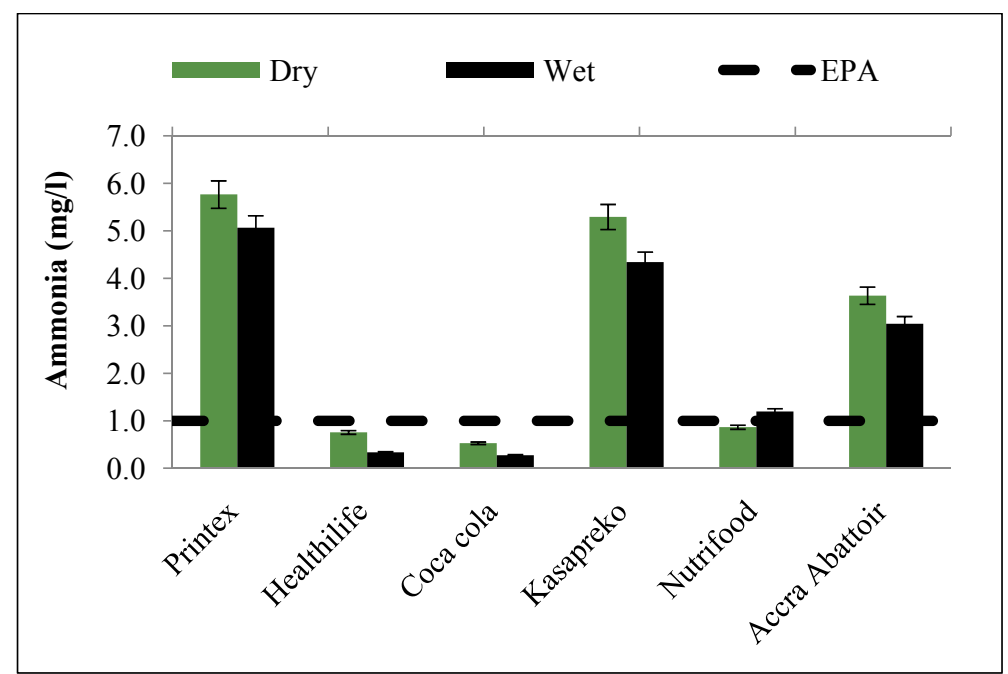

Fig. 21 Ammonia of the industries.

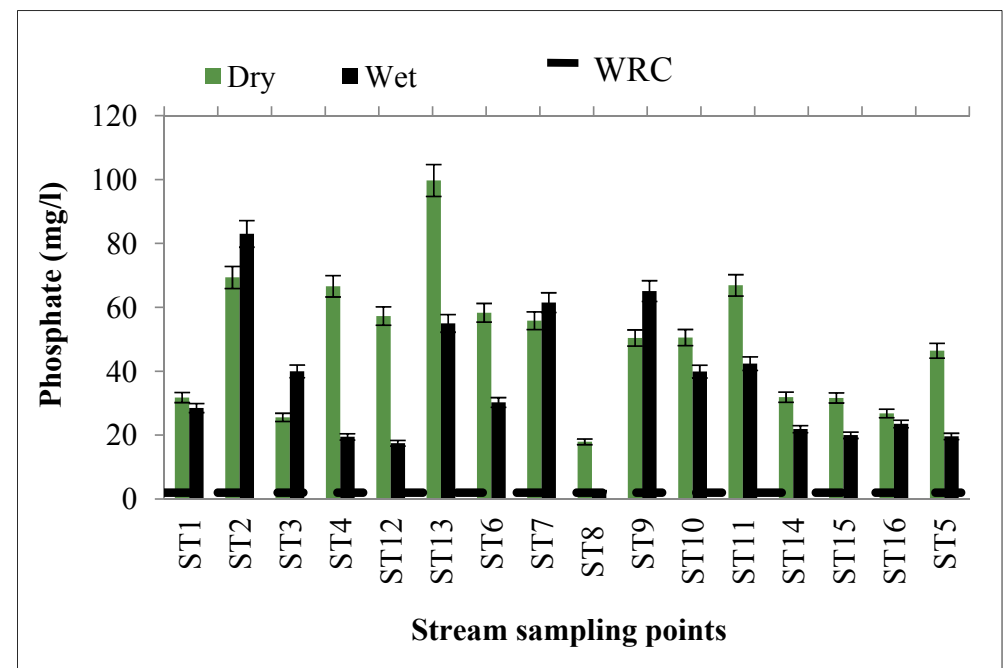

Fig. 22 Phosphate of the stream. 


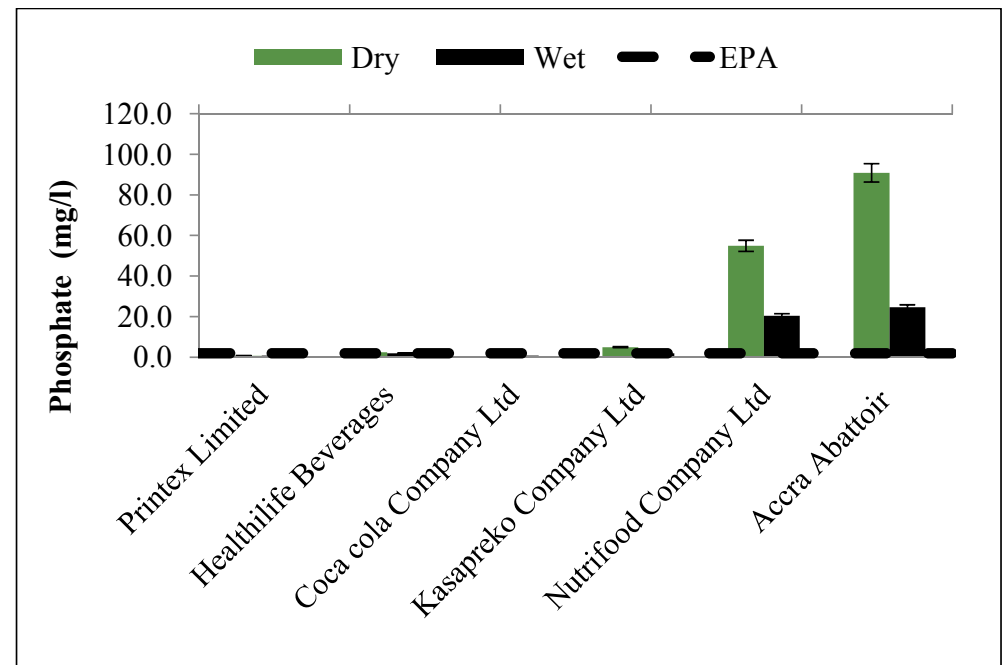

Fig. 23 Phosphate of the industries.

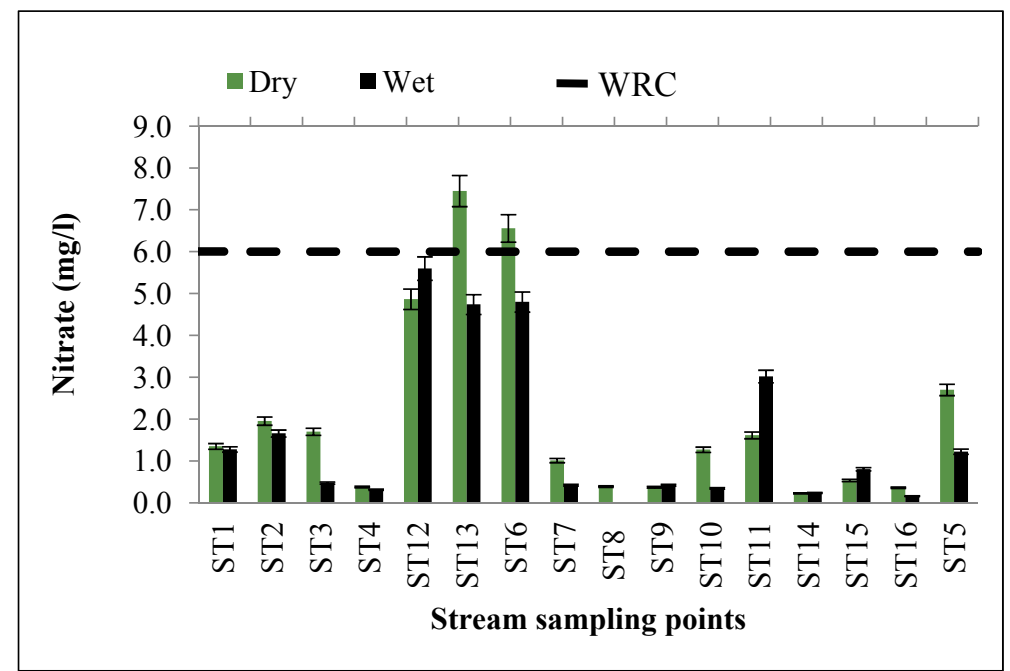

Fig. 24 Nitrate of the stream.

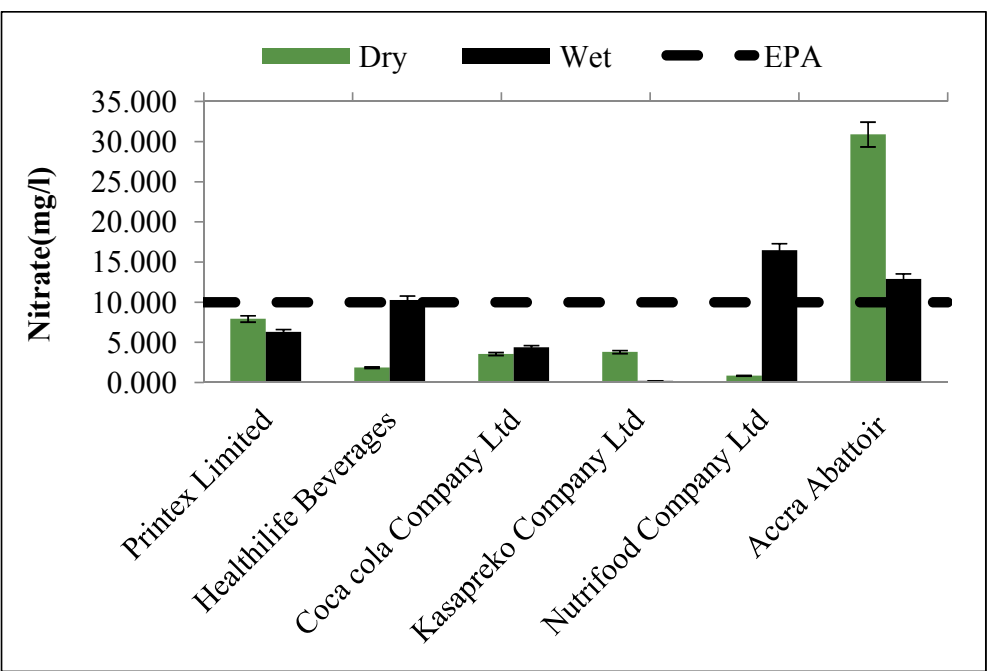

Fig. 25 Nitrate of the industries. 


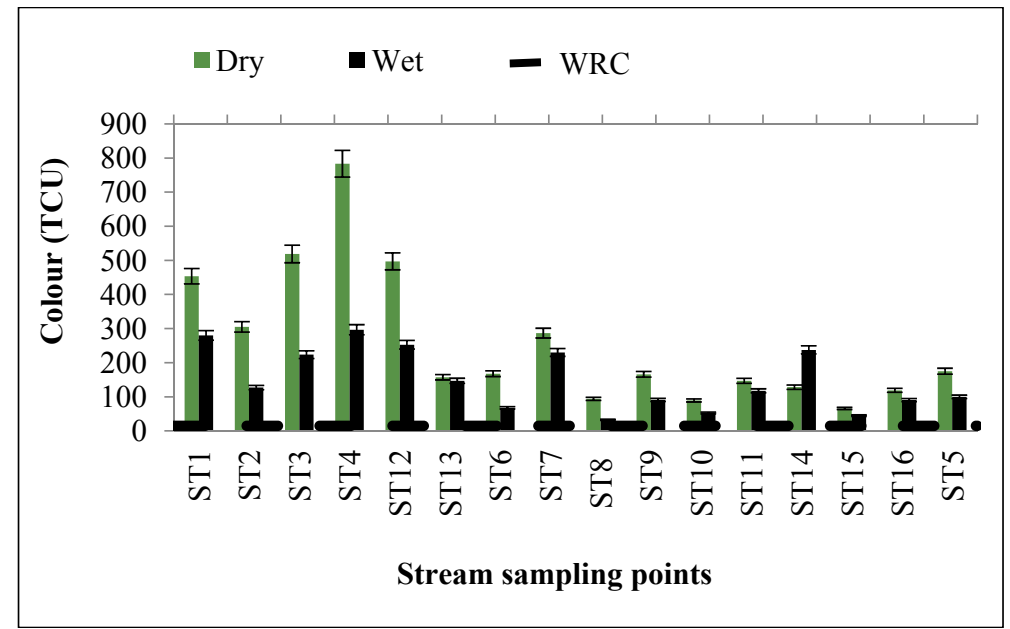

Fig. 26 Colour of the stream.

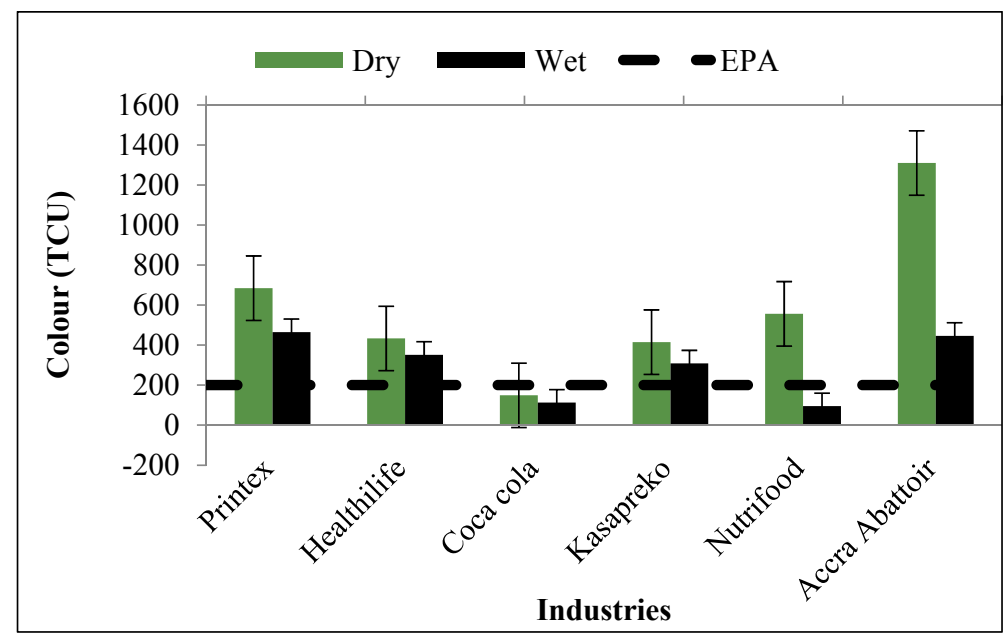

Fig. 27 Colour of the industries.

value of $(24.6 \mathrm{mg} / \mathrm{L} \& 90.83 \mathrm{mg} / \mathrm{L})$ in the effluent of industry EF6 (Abattoir) in both period (Fig. 23). Moreover, the phosphate concentrations observed in the stream were above the WRC raw water quality guideline values the "no effect" range of $0-2 \mathrm{mg} / \mathrm{L}$ [16]. This is an indication of pollution loads in the Onukpawahe stream, while the phosphate levels in recorded in the effluent samples were above the EPA effluent quality guideline value of $2 \mathrm{mg} / \mathrm{L}$ [22]. The results of the current study (Onukpawahe stream) which is a tributary of the Sakumonu Lagoon were very high compared to the results of similar studies by Refs. $[4,31]$ in Sakumonu Lagoon which ranges from $1.97 \mathrm{mg} / \mathrm{L}$ to $4.72 \mathrm{mg} / \mathrm{L}$ and from $0.01 \mathrm{mg} / \mathrm{L}$ to $2.90 \mathrm{mg} / \mathrm{L}$ respectively. Available literature $[4,18]$ indicates that industrial effluent, fertilizer runoff, domestic effluents particularly which contain detergents, are the main reasons of high phosphate levels in surface water such as streams, rivers and lakes. The high concentrations of phosphate in the Onukpawahe stream where most of the industries are located is an indication of some level pollution by these industries which will lead to eutrophication condition which reduce the dissolved oxygen in the stream causing danger to aquatic life [30].

\subsubsection{Nitrate-nitrogen}

The nitrate levels recorded was found to be between $0.01 \mathrm{mg} / \mathrm{L}$ and $5.60 \mathrm{mg} / \mathrm{L}$ in during the wet period and $0.23 \mathrm{mg} / \mathrm{L}$ to $7.45 \mathrm{mg} / \mathrm{L}$ during the dry period (Fig. 24). In the present study, the nitrate levels in the collected effluent samples varied from a low value of $0.223 \mathrm{mg} / \mathrm{L}$ in the wastewater of 
industry EF2 to a high of $30.9 \mathrm{mg} / \mathrm{L}$ in the wastewater of industry EF6 (Abattoir) (Fig. 25). The nitrate levels recorded in the stream were within the WRC raw water quality guideline "no effect" range of 0-6 $\mathrm{mg} / \mathrm{L}$ [15] except site ST13 and ST6 which were higher during the dry season while the nitrate levels in the effluent samples were also within effluent quality guideline of $10 \mathrm{mg} / \mathrm{L}$ by EPA except EF6 [22] a slaughter house. The nitrate concentration varied insignificantly along the sampling site the ANOVA $(\mathrm{P}=0.722, \mathrm{P}>0.05)$. From available literature [31, 29] indicates that the major sources of nitrate are industrial waste, food preservatives, organic pollutants rich in nitrogen, runoff from farm lands, leaks from manholes and animal waste from Abattoirs [30]. According to Ref. [25], high levels of nitrates in streams used source of potable water are associated with methaemoglobinaemia in bottle-fed infants referring as blue baby syndrome. According to Ref. [18], nitrate is relatively nontoxic for fish health, except when the concentration of nitrate exceed above $90 \mathrm{mg} / \mathrm{L}$ in water. The receiving water stream of this effluent loses much of aquatic life and intense consequences due to microbes, oxygen demand load and ecological disturbance

\subsubsection{Sulphate}

The sulphate concentration in the stream sample ranges from $5.53 \mathrm{mg} / \mathrm{L}$ to $108 \mathrm{mg} / \mathrm{L}$ in the dry period and varied from $0.01 \mathrm{mg} / \mathrm{L}$ to $65 \mathrm{mg} / \mathrm{L}$ in the wet period (Fig. 16). However, the sulphate levels in the effluent samples were found to be between a low value of $0.54 \mathrm{mg} / \mathrm{L}$ in the effluent of industry EF4 (alcoholic beverage) and a high value of $68 \mathrm{mg} / \mathrm{L}$ in the effluent of industry EF1 (Textile) (Fig. 17). The sulphate concentration of the stream water samples in the current study were within the WRC raw water quality guideline values the "no effect" range of $0-200 \mathrm{mg} / \mathrm{L} \mathrm{[16],} \mathrm{while} \mathrm{the} \mathrm{sulphate} \mathrm{levels} \mathrm{in}$ effluents samples were within the EPA acceptable value of $200 \mathrm{mg} / \mathrm{L}$ [22]. Moreover, there was statistically significant difference between the concentrations among sampling sites on the stream (ANOVA, $\mathrm{P}=0.006, \mathrm{p}<0.05$ ). The sharp rise in the concentration of sulphate recoded at the site ST13 the immediate downstream of the discharge points of the beverage and textile industries is an indication of discharge of industrial effluent into the stream by these industries. From available literature [30], the major sources of sulphate in stream are rock weathering, volcanoes, and human activities such as mining, industrial effluent discharge, and fossil fuel combustion process. The bioaccumulation of the inorganic substances such as sulphate $(5.35 \mathrm{mg} / \mathrm{L}$ to $108 \mathrm{mg} / \mathrm{L}$ ) could result in reduction in the level of dissolved oxygen and proliferation of nutrient [25]. This could create threat to aquatic life and when reach a concentration of $1,000 \mathrm{mg} / \mathrm{L}$ causes laxative effects and gastrointestinal irritation [18].

\subsubsection{Biochemical Oxygen Demand (BOD)}

The BODin the stream samples was between 79 $\mathrm{mg} / \mathrm{L}$ lowest at site ST16 and $677 \mathrm{mg} / \mathrm{L}$ highest at site ST1 in the dry period, whereas in the wet period a lowest of $83 \mathrm{mg} / \mathrm{L}$ at site ST14 to the highest of 554 $\mathrm{mg} / \mathrm{L}$ at site ST1 ( Fig. 14). However, the levels of BOD in the industrial effluent ranged from a low of $166 \mathrm{mg} / \mathrm{L}$ in the effluent of industry EF1 (textile) to a high of $1,4838 \mathrm{mg} / \mathrm{L}$ in the effluent of industry EF6 (Slaughter house) (Fig. 15). Moreover, the BOD recorded in stream water samples were far higher than the WRC raw water quality guideline values the "no effect" range of $0-30 \mathrm{mg} / \mathrm{L}[16]$ and this is an indication of pollution of the stream and the level in the effluents samples were above the acceptable effluent quality guideline values of $50 \mathrm{mg} / \mathrm{L}$ by EPA. Furthermore, the (ANOVA, $p=0.002, p<0.05$ ) indicates significant differences between the concentration of the sites. The high BOD concentration at these sampling locations on the stream is attributed to the discharge of industrial effluent with high levels of organic compounds, decay of dead plants other source such runoff from farm lands, and septic tanks leaks. Similar 
observations were made by Phiri, et al. [6] and Ugwu and Wakawa [32]. From available literature [26] indicates that BOD concentration has direct influence on dissolved oxygen content of water body. The impact of releasing this high BOD concentration is anaerobic conditions which could influence an aquatic environment, fatality of fishes, stench and unpleasant disturbance.

\subsubsection{Chemical Oxygen Demand (COD)}

The COD concentrations of the stream water samples were found to be between least $83 \mathrm{mg} / \mathrm{L}$ at site ST14 and highest of $554 \mathrm{mg} / \mathrm{L}$ at site ST1 in the wet period, whilst in the dry period least $119 \mathrm{mg} / \mathrm{L}$ at site ST16 and high $977 \mathrm{mg} / \mathrm{L}$ at site ST1 (Fig. 18). However, the COD levels in the industrial effluent samples were between a least value of $218 \mathrm{mg} / \mathrm{L}$ in the wastewater of industry EF3 (Beverage) and the highest of $14,436 \mathrm{mg} / \mathrm{L}$ in the effluent of EF6 (Abattoir) in the wet period (whilst in the dry period least $119 \mathrm{mg} / \mathrm{L}$ at site ST16 and high $977 \mathrm{mg} / \mathrm{L}$ at site ST1 (Fig. 19). The observed COD levels in the stream were far higher than the WRC raw water quality guideline "no effect" range of 0-75 $\mathrm{mg} / \mathrm{L}[16]$ and that in the effluent effluents samples were above the EPA effluent quality guideline values of $250 \mathrm{mg} / \mathrm{L}$ [22]. Moreover, differences of COD concentration were statistically significant between sites (ANOVA, $\mathrm{P}=0.002, P<0.05)$. The presence of this level of COD is manifestation of pollution of the stream water body due to wide usage of chemical and organic fertilizer and discharge of effluent including sewerage by anthropogenic activities. The results of previously published work [26, 33] agree with this current manifestation of the effects of factory wastewater on the quality of the Onukpawahe stream. The presence of high level of COD especially EF6 (slaughter house) is an indication of production of wide range of waste such as coagulated blood, chemicals used in production process, organic, inorganic substances and dyestuff by these factories. When effluents are discharge into the stream, the consequences are that it impairs light penetration, oxygen depletion and leads to reduction in photosynthesis in plant. The fauna and flora are being influenced.

\section{Conclusions}

In general, the impact of industrial effluents on the quality of the Onukpawahe stream at the Tema Motorway Industrial Area, Tema is patent. This is explained by the fact that there was a general increase in the concentration of the parameters analysed downstream after each discharge point as compared to upstream sites. Strident neglect of the environment and surface water bodies portrayed through rampant discharge of high concentration effluents into the Onukpawahe stream without any form of effective treatment may result in the accumulation of the contaminants. This may affect the lives of human as well as aquatic animals in the Onukpawahe stream. Authors' findings imply that the quality of the stream has been compromised by the discharge of untreated effluent into the Onukpawahe stream evidenced by high levels of BOD, COD and nutrients discharge into the stream by these industries. To avert further deterioration of the quality of the stream, there is a need for the regulatory bodies like Environmental Protection Agency (EPA) and Water Resources Commission (WRC) to undertake rigorous monitoring of the industrial effluents to ensure their qualities acceptable before discharging them to the water bodies.

\section{Acknowledgement}

The authors would like to express their sincere gratitude to the Environmental Protection Agency, Ghana and Department of Civil Engineering, KNUST for the use of the agencies laboratory facility and assistance respectivel.

\section{References}

[1] Shivayogimath, C. B., Kalburgi, P. B., Deshannavar, U. B., and Virupakshaiah, D. B. M. 2012. "Water Quality Evaluation of River Ghataprabha, India." Indian Research Journal of Environment Sciences 1 (1): 12-18. 
[2] Bartram, J., and Balance, R. 1996. A Practical Guide to the Design and Implementation of Water Quality Studies and Monitoring Programmes. London: Chapman \& Hall.

[3] Agbemehia, K. 2013. "Effects of Industrial waste Effluent Discharged into Sakumono II Lagoon in Accra Ghana." Department of Theoretical ans Applied Biology (Kwame Nkrumah University of Science and Technology, Kumasi). Accessed December 18, 2015. www.KNUST DSPACE.com.

[4] Nartey, V. K., Edor, K. A., Doamekpor, L. K., and Bobobee, L. H. 2011. "Nutrient Load of the Sakumo Lagoon at the Sakumo Ramsar Site in Tema, Ghana." West African Journal of Applied Ecology 19 (1).

[5] Okeola, F. O., Kolawole, O. D., and Ameen, O. M. 2010. "Comparative Study of Physico Chemical Parameters of Water from a River and its Surrounding Wells for Possible Interactive Effect.” Water 4 (3): 336-340.

[6] Phiri, O., Mumba, P., Moyo, B. H. Z., and Kadewa, W. 2005. "Assessment of the Impact of Industrial Effluents on Water Quality of Receiving Rivers in Urban Areas of Malawi." International Journal of Environmental Science and Technology 2 (3): 237-244.

[7] Koshy, M. N. T. 1999. "Water Quality Aspects of River Pamba." Pollution Research 18 (4): 501-510.

[8] Aboyeji, O. O. 2013. "Freshwater Pollution in Some Nigerian Local Communities, Causes, Consequences and Probable Solutions." Academic Journal of Interdisciplinary Studies 2 (13): 111.

[9] Bernard, A. 2010. "Assessing the Performance of Dompoase Wastewater Treatment Plant and Its Effect on Water Quality of the Oda River in Kumasi.” Ph.D. thesis, Kwame Nkrumah University of Science and Technology.

[10] Morrison, G., Fatoki, O. S., Persson, L., and Ekberg, A. 2001. "Assessment of the Impact of Point Source Pollution from the Keiskammahoek Sewage Treatment Plant on the Keiskamma River-pH, Electrical Conductivity, Oxygen-demanding Substance (COD) and Nutrients." Water SA 27 (4): 475-480.

[11] Wagtech. 2015. Wagtech Potalab Instructions Manual, London. Accessed October 21 2015. www.wagtech.co.uk.

[12] YSI, I. 2014. "YSI 9300 and 9500 Photometers User Manual YSI 9300 and 9500 Direct-Read Photometers User Manual.” Brannum Lane Yellow Springs. Accessed October 21 2015. www.YSI.com.

[13] APHA, A. 1992. WEF, Standard Methods for the Examination of Water and Wastewater (18th ed.) Washington, D. C.: American Public Health Association.

[14] Ijeoma, K., and Achie, O. K. 2011. "Industrial Effluents and their Impact on Water Quality of Receiving Rivers in Nigeria." Journal of Aapplieal Technology in Environmental Sanitation 1 (1): 75-86.

[15] Water Resources Commission. 2003. "WRC. (2003)."
Ghana Raw Water Criteria and Guidelines Vol. 1.

[16] Agyemang, E. O., Awuah, E., Darkwah, L., Arthur, R., and Osei, G. 2013. "Water Quality Assessment of a Wastewater Treatment Plant in a Ghanaian Beverage Industry." International Journal of Water Resources and Environmental Engineering 5 (5): 272-279.

[17] Yeboah, D. 2015. Odour Control of a Biological Wastewater Facility (Kwame Nkrumah University of Science and Technology, Kumasi). Accessed December 25, 2015. www.KNUSTDSPACE.com.

[18] Fakayode, S. O. 2005. "Impact Assessment of Industrial Effluent on Water Quality of the Receiving Alaro River in Ibadan, Nigeria." African Journal of Environmental Assessment and Management 10: 1-13.

[19] YSI, I. 2014. "YSI 9300 and 9500 Photometers User Manual YSI 9300 and 9500 Direct-Read Photometers User Manual.” Brannum Lane Yellow Springs. Accessed October 21, 2015. www.YSI.com.

[20] Ijeoma, K., and Achie, O. K. 2011. "Industrial Effluents and their Impact on Water Quality of Receiving Rivers in Nigeria." Journal of Aapplieal Technology in Environmental Sanitation 1 (1): 75-86.

[21] Ipeaiyeda, A. R., and Onianwa, P. C. 2011. "Pollution Effect of Food and Beverages Effluents on the Alaro River in Ibadan City, Nigeria." Bulletin of the Chemical Society of Ethiopia 25 (3): 347-360.

[22] Hasan, K., and Miah, M. 2014. "Impacts of Textile Dyeing Industries Effluents on Surface Water Quality: A Study on Araihazar Thana in Narayanganj District of Bangladesh." Journal of Environment and Human 1 (3): 8-23.

[23] Lokhande, R. S., Singare, P. U., and Pimple, D. S. 2011. "Pollution in Water of Kasardi River Flowing along Taloja Industrial Area of Mumbai, India." World Environment 1 (1): 6-13.

[24] Adeogun, A. O. 2012. "Impact of Industrial Effluent on Water Quality and Gill Pathology of Clarias Gariepinus from Alaro Stream Ibadan, Southwest, Nigeria." Europian Journal of Scientific Research 76: 83-94.

[25] EPA. 2012. Environmental Quality Standards Applied for AKOBEN Ratings for the Manufacturing Sector Environmental Quality Standards Applied for AKOBEN Ratings for the Manufacturing Sector. Environmental Protection Agency, Accra, Ghana.

[26] Diya'uddeen, B. H., Udiba, U. U., Balli Gauje, A. N., Okezie, V. C., Gero, M., Saleh, A. M., et al. 2014. "The Impact of Industrial Effluents from Dakace Industrial Area on the Physicochemical Properties of River Galma, Zaria, Nigeria." Pelagia Research Library 5 (6): 174-184.

[27] Monney, I., Boakye, R., Buamah, R., Anyemedu, F. O. K., Odai, S. N., et al. 2013. "Urbanization and Pollution of Surface Water Resources in the Two Largest Cities in 
Ghana." Int. J. Environ. Monitoring Anal 1: 279-287.

[28] Sirohi, S., Sirohi, S. P. S., and Tyagi, P. K. 2014. "Impact of Industrial Effluents on Water Quality of Kali River in Different Locations of Meerut, India." Journal of Engineering and Technology Research 6 (4): 43-47.

[29] Walakira, P. 2011. "Impact of Industrial Effluents on Water Quality of Receiving Streams in Nakawa-Ntinda Uganda." Ph.D. thesis, Makerere University.

[30] Ipeaiyeda, A. R., and Onianwa, P. C. 2011. "Pollution Effect of Food and Beverages Effluents on the Alaro River in Ibadan City, Nigeria." Bulletin of the Chemical Society of Ethiopia 25 (3): 347-360.
[31] Fawaz, A., Shuhaimi-Othman, M., and Gasim, M. B. 2013. "Water Quality Assessment of the Semenyih River, Selangor, Malaysia." Journal of Chemistry.

[32] Ugwu, A. I., and Wakawa, R. J. 2012. "A Study of Seasonal Physicochemical Parameters in River Usma." American Journal of Environmental Sciences 8 (5): 569-576.

[33] Attiogbe, F. K., Glover-Amengor, M.. and Nyadziehe, K. T. 2009. "Correlating Biochemical and Chemical Oxygen Demand of Effluents-A Case Study of Selected Industries in Kumasi, Ghana." West African Journal of Applied Ecology 11 (1): 1-11. 